Jurnal Interpretasi Hukum | ISSN: XXXX | E-ISSN: XXXX

Vol. 1, No. 2 - September 2020, Hal. 138-141| Available online at https://www.ejournal.warmadewa.ac.id/index.php/juinhum DOI: http://doi.org/10.22225/juinhum.v1i2.2451. 138-141

\title{
PENGAWASAN PEMERINTAH DAERAH TERHADAP USAHA PERTAMBANGAN GALIAN C DI KABUPATEN NGADA
}

\author{
Matius Ade Krispian Soba Nono, I Ketut Kasta Arya Wijaya, Luh Putu Suryani \\ Fakultas Hukum Universitas Warmadewa, Denpasar-Bali, Indonesia \\ adesobanono@gmailcom, kastaaryawijaya@gmailcom, suryanifhwjurnal@gmailcom
}

\begin{abstract}
Abstrak
Pertambangan mineral batuan jenis pasir batu dan kerikil termasuk komoditas tambang yang dilakukan masyarakat desa Naru dimana diperlukan pengawasan oleh Pemerintah Daerah Namun masih terdapat masalah dalam pengawasan aktivitas pertambanggan galian $\mathrm{C}$ yang tidak sesuai dengan kaidah pertambangan Penelitian ini bertujuan untuk mengetahui Peranan Pemerintah daerah dalam pengawasan kegiatan pertambangan galian $\mathrm{C}$ serta faktor yang mempengaruhi adanya kegiatan penambangan galian $\mathrm{C}$ di Kabupaten Ngada Penelitian menggunakan Metode hukum empiris artinya suatu penelitian mengkaji permasalahan sesuai fakta yang terjadi di lapangan. Hasil penelitian menunjukan Pemda Kabupaten Ngada tidak lagi memiliki kewenangan dalam pengawasan pertambangan dimana sudah diambil alih oleh Pemerintah Daerah Provinsi sejak dikeluarkannya Undang-undang NO. 23 Tahun 2014 tentang Pemerintah Daerah yang membuat proses pengawasan dan perizinan pertambangan cukup terhambat yang kedua penambang dan perusahaan pemilik pertambangan dipersulit dalam pengajuan perizinan karena para pemilik usaha harus mengurus izin pertambangan ke Pemerintah Daerah Provinsi mengingat jarak yang sangat jauh hal ini merupakan salah satu faktor yang menyebabkan banyaknya kegiatan pertambangan galian C ilegal terjadi di Kabupaten Ngada
\end{abstract}

Kata Kunci: Pengawasan; Pertambangan galian C; Izin usaha pertambangan

\begin{abstract}
Mining of rock minerals in the sandstone and gravel type is a mining commodity owned by the people of Naru village which requires supervision by the local government. Unfortunately, there are still problems in monitoring mining activities of excavation $C$, which are not in accordance with mining principles. This study aims to determine the role of the local government in the supervision of mining excavation $C$ as well as the factors that influence the existence of the C mining activities in Ngada Regency. This research uses an empirical legal method, which is a study examining problems according to facts that take place in the field. The results show that the Ngada Regency Government no longer has the authority to supervise the mining since it has been taken over by the Provincial Government, starting with the issuance of Law No. 23 of 2014 concerning the Regional Government. The factor hampering the mining supervision and licensing process is that it is difficult for miners and mining companies to apply for permits whereas business owners are obliged to obtain mining permits from the Provincial Government. Given the great distance, this has been one of the factors causing many illegal mining activities to occur in Ngad Regency.
\end{abstract}

Keywords: Supervision; Mining; Excavation C; Mining license

\section{PENDAHULUAN}

Indonesia merupakan Negara kepulauan yang memiliki sumber daya alam berlimpah yang menjadikannya sebagai sumber terbesar devisa negara dimana segala bentuk pengelolaan kekayaan alam diatur dalam Undang-Undang dan diperuntukan bagi kesejahteraan masyarakat Pentingnya memberikan perhatian yang serius terhadap pengelolaan sumberdaya alam sebagaimana disebutkan di atas, dikarenakan Indonesia merupakan negara yang memiliki kekayaan yang melimpah (Efendi, 2014). Menurut Kombes Indonesia memiliki berbagai sumber kekayaan alam sebagai pendukung pariwisata yang perlu dikembangkan, yang hasilnya digunakan untuk kesejahteraan dan kemakmuran rakyat, untuk tanggung jawab mengendalikan sumber kekayaan alam sebagai pendukung pariwisata berada pada negara yang pelaksanaan pengelolaannya ditangan pemimpin nasional. Dalam 
pengembangan pariwisata Indonesia agar selalu memperhatikan beberapa hal meliputi: faktor-faktor pendorong kegiatan kepariwisataan, sumber daya pariwisata dan objek daerah tujuan wisata, peluang dan kendala serta tantangan yang dihadapi dalam pengembangan pariwisata (Nugroho, 2016).

Negara memberikan kewenangan pengelolaan pertambangan kepada pemerintah daerah seperti yang tertuang dalam Undang-Undang Nomor 30 tahun 2004 tentang pemerintah daerah. Dalam Undang- Undang tersebut mengatakan bahwa negara memberikan kewenangan pemerintah daerah untuk mengolah dan mengeksplorasi segala bentuk sumber daya alam yang ada dalam wilayah otonomi daerah tersebut. Menurut suhartono pembagian wilayah suatu Negara ke dalam daerah besar dan kecil diharapkan dapat melahirkan otonomi daerah yang luas yang memungkinkan daerah memiliki kewenangan otonom dalam mengurus rumah tangganya sendiri termasuk dalam melakukan pengelolaan sumber daya alam (Suhartono, 2013).

Berdasarkan hasil observasi terhadap lokasi sumber daya alam di kabupaten Ngada masih terdapat banyak warga yang memanfaatkan lahan milik pribadi menjadi lahan pertambangan galian $\mathrm{C}$ yang dimana tidak dilengkapi dengan izin dari pemerintah daerah khususnya di kabupaten Ngada Pemanfaatan tanah pribadi sebagai lokasi usaha pertambangan bahan galian $\mathrm{C}$ oleh masyarakat merupakan kegiatan usaha pertambangan yang masih dikelola oleh masyarakat setempat secara sederhanaHal ini merupakan salah satu faktor bagi Pemerintah Daerah Kabupaten Ngada kesulitan untuk mengawasi warganya melakukan aktivitas pertambangan tersebut Dalam implementasinya pelaksanaan usaha pertambangan tersebut tidak dapat menunjang pembangunan berkelanjutan sebagaimana diatur dalam Undang- undang Nomor 32 Tahun 2009 tentang perlindungan dan pengelolaan lingkungan hidup. Iriantini menyatakan bahwa Perusahan yang melakukan kegiatan memerlukan suatu kepastian hukum untuk menjalankan usahananya dalam pengelolaannya membutuhkan peran serta pemerintah untuk mengawasi dan mengendalikan setiap kegiatan yang dilakukan oleh pengusaha termasuk pemberian ijin usaha kepada masyarakat (Takalapeta et al., 2019).

Sebagaimana telah diatur pada Peraturan Daerah Provinsi Nusa Tenggara Timur Nomor 8 tahun 2010 Tentang Pengolahan Pertambangan Mineral dan Batubara mengingat bahwa mineral dan batubara merupakan sumber daya alam tak terbarukan pengelolaan pengusahaannya perlu dilakukan seoptimal mungkin yang dimana semua kegiatan usaha pertambangan wajib memiliki izin dan pengetahuan tentang pelestarian Kawasan pertambangan Berdasarkan ketentuan dalam Pasal 1 Angka 7 Undang-undang Nomor 4 Tahun 2009 terdapat pengertian tentang Izin Usaha Pertambangan (IUP) yang berarti setiap orang atau badan hukum yang melakukan kegiatan pertambangan wajib memiliki izin. Menurut (Soekanto, 2013) tolak ukur efektivitas penegakan hukum ada lima hal yakni :

1. Faktor Hukum hukum berperan terhadap kepastian kepentingan dan keadilan

2. Faktor penegakan hukum Dalam berjalannya hukum secara normal mental atau kepribadian aparat penegak hukum memegang peranan penting jika peraturan perundang-undangan baik tetapi kualitas aparaturnya tidak tinggi maka akan timbul masalah

3. Faktor sarana atau fasilitas pendukung faktor sarana atau fasilitas pendukung kerja aparat penegak hokum

4. Faktor masyarakat permasalahan yang muncul adalah tingkat kepatuhan hukum di masyarakat

5. Faktor kebudayaan budaya pada dasarnya mencakup nilai-nilai hukum yang berlaku

Berdasarkan paparan masalah di atas maka yang menjadi tujuan dalam penelitian ini adalah Bagaimana peranan pemerintah daerah dalam pengawasan kegiatan usaha pertambangan galian $\mathrm{C}$ di Kabupaten Ngada, serta mengetahui faktor-faktor yang mempengaruhi adanya penambangan galian C di Kabupaten Ngada

\section{METODE PENELITIAN}

Penelitian ini merupakan penelitian hukum normatif atau doktrinal yaitu penelitian terhadap data sekunder yang berupa bahan hukum primer, bahan hukum sekunder, dan bahan hukum tersier (Takalapeta et al., 2019). Dalam pengumpulan data di lapangan teknik yang digunakan adalah teknik wawancara atau interview. Teknik wawancara atau interview adalah suatu cara memperoleh informasi untuk tujuan penelitian dengan cara melakukan Tanya jawab secara langsung (tatap muka) antara pewawancara dengan informan. Dalam penelitian ini data diperoleh dari pihak-pihak yang terkait dalam masalah yang diteliti dalam hal ini pihak pemerintah Kabupaten Ngada Pemilik tempat pertambangan Para penambang dan masyarakat di sekitar area pertambangan. Analisisnya melalui 
interpretasi dengan tetap memperhatikan konsistensi antara teori hukum, asas hukum dan kaidah hukum yang relevan dengan permasalahan dalam penelitian ini.

\section{HASIL PENELITIAN DAN PEMBAHASAN}

\section{Kewenangan Pemerintah Daerah terhadap Kegiatan UsahaPertambangan}

Kewenangan merupakan kekuasaan membuat keputusan memerintah dan memberi tanggung jawab kepada orang lain. Kewenangan itu sendiri ialah kekuasaan yang diformalkan untuk orang-orang tertentu atau kekuasaan terhadap bidang pemerintahan tertentu yang berasal dari kekuasaan legislatif maupun dari pemerintah (Sadjijono, 2008). Sanksi merupakan salah satu cara untuk memperkuat perilaku sipil tersebut Oleh karena itu sanksi merupakan bagian yang melekat pada norma hukum tertentu

Sanksi ada yang berupa peringatan tertulis dan ada yang berupa peringatan secara lisan. Menurut (HR, 2003). Secara umum dikenal beberapa macam sanksi dalam hukum administrasi yaitu kewenangan dalam pengawasan Pertambangan tersebut berada di tangan Pemerintah Daerah sesuai dengan Pasal 4 ayat (2) Undang-Undang Nomor 4 Tahun 2009 tentang Pertambangan Mineral dan Batubara disebutkan bahwa penguasaan mineral dan batubara oleh Negara sebagaimana dimaksud pada ayat (1) diselenggarakan oleh Pemerintah dan/Pemerintah Daerah artinya mulai dari proses perizinan sampai dengan pengawasan kegiatan pertambangan dijalankan oleh Pemerintah Daerah Provinsi untuk tambang yang berada di lintas wilayah 4 (empat) mil sampai dengan 12 (dua belas) mil dan Pemerintah Daerah Kabupaten/Kota untuk tambang sampai dengan jarak 4 (empat) mil Setelah berlakunya UU NO 23 Tahun 2014 tentang pemerintahan daerah dalam hal penyelenggaraan urusan pemerintah di bidang pertambangan mineral dan batubara dimana pada pasal 14 ayat (1) menyebutkan bahwa penyelenggaraan urusan pemerintah di bidang sumber daya mineral dibagi atas pemerintah Pusat dan Daerah Provinsi. Berdasarkan hal tersebut tidak ada lagi kewenangan yang dimiliki oleh pemerintah daerah kabupaten/kota. Pengawasan merupakan suatu pengamatan terhadap semua kegiatan untuk memastikan bahwa semua kegiatan dilaksanakan sesuai dengan rencana yang telah ditetapkan Selain itu dalam perspektif hukum administrasi nasional pengawasan merupakan suatu proses kegiatan yang digunakan untuk membandingkan apakah suatu hal telah dilaksanakan diselesaikan atau diatur dan dibandingkan dengan hal- hal yang diharapkan direncanakan atau dipesan (Siagian, 1987).

\section{Faktor-faktor yang Mempengaruhi Adanya Kegiatan Usaha Pertambangan Galian C Iegal di Kabupaten Ngada}

Dalam perjalanannya kegiatan penambangan ini menunjukkan indikasi melanggar Surat Izin Pertambangan Pada Surat Izin Pertambangan dijelaskan bahwasannya pengelolaan pertambang rakyat tidak diperkenankan menggunakan alat berat dan peralatan yang diizinkan dimana dalam penambangan pada lokasi petambang rakyat yang dibolehkan adalah linggis sekop dan pakuel namun loader dan eskavator hanya dapat digunakan untuk mengikis permukaan tanah dan pembersihan lokasi Meski regulasi sudah ditetapkan tambang rakyat masih menggunakan alat berat seperti loader dan eskavator. Menurut (Hadjon, 1993) secara umum intinya adalah ketika peraturan administrasi nasional tidak dapat menegakkan aturan perilaku tersebut maka peraturan administrasi nasional tidak mencantumkan larangan dan kewajiban bagi warga negara

Ada dua faktor yang mempengaruhai danya kegiatan usaha pertambangan ilegal di Kabupaten Ngada yitu Faktor Eksternal meliputi masih rendahnya kesadaran pelaku usaha pertambangan rakyat untuk mengurus dokumen perizinan tambang, kurangnya kesadaran pemegang IUP untuk menyampaikan laporan kegiatan kepada dinas ESDM Provinsi NTT dan Kurangnya kerjasama dari masyarakat sekitar pertambangan untuk melaporkan kegiatan pertambangan illegal selanjutnya faktor Internal yaitu masih kurangnya personil pegawai yang dimiliki oleh dinas ESDM, minimnya anggaran yang dialokasikan untuk kegiatan pengawasan usaha pertambangan dan Sosialisasi tentang pertambangan rakyat yang kurang merata

\section{SIMPULAN DAN SARAN \\ 1 Simpulan}

Peranan Pemerintah Daerah dalam pengawasan kegiatan usaha pertambangan galian C di Kabupaten Ngada dengan diundangkannya Undang-undang Nomor 23 Tahun 2014 tentang pemerintahan daerah dalam hal penyelenggaraan urusan pemerintah bidang pertambangan mineral dan batubara mengatur 
penyelenggaran urusan pemerintah di bidang sumber daya mineral dibagi atas pemerintah Pusat dan Daerah Provinsi Berdasarkan hal tersebut Pemerintah Kabupaten/Kota tidak lagi memiliki kewenangan Karena kegiatan Pertambang berada di wilayah Pemerintah Daerah Kabupaten/kota maka Pemerintah Daerah Kabupaten/Kota sampai saat ini masih bersama-sama dengan Pemerintah Daerah Provinsi mengawasi usaha pertambangan yang dilakukan di daerah-daerah Kabupaten/kota Mulai dari melakukan sosialisasi pembinaan pengawasan titik koordinat wilayah pertambangan dan melakukan penertiban atau razia penambang yang tidak mengikuti aturan-aturan yang telah ditetapkan serta mengamati kerusakan- kerusakan lingkungan bersama Kantor Lingkungan Hidup (KLH) daerah dan Badan Pengendalian Dampak Lingkungan Daerah (Bapedalda) Provinsi Nusa Tenggara Timur. Faktor-faktor yang mempengaruhi adanya penambangan galian $\mathrm{C}$ di kabupaten Ngada diakibatkan sulitnya ekonomi menjadi salah satu faktor yang mempengaruhi adanya penambangan liar rata-rata pekerjaan utama penambang adalah petani dan kegiatan operasi penambangan adalah pekerjaan sampingan yang menghasilkan tambahan pendapatan dan minimnya personel untuk mengawasi kegiatan pertambangan dan sosialisasi membuat banyak penambang tidak mendapatkan sosialisasi dari pemerintah sehingga sulit bagi Dinas ESDM untuk mengawasi perusahaan-perusahaan tambang kecil yang tersebar disekitar pertambangan yang dikategorikan ilegal.

\section{Saran}

Ada bebrapa yang disarankan peneliti antara lain sebagai berikut:

1. Peneliti menyarankan agar pemerintah lebih memperhatikan pengawasan terhadap perusahaanperusahaan dan wilayah pertambang di daerah Kabupaten Ngada untuk mengetahui bagaimana kepastian IUP yang dimiliki oleh perusahaan tersebut jika melanggar ketentuan perusahaan wajib untuk mengembalikan IUP yang mereka miliki Setelah IUP dikembalikan maka pemerintah dapat memberikan IUP tersebut kepada perusahaan tambang yang lebih kompeten sanggup mengelola usaha pertambangan tersebut sehingga potensi mineral di daerah Kabupaten Ngada dapat diolah sebesar-besarnya untuk kepentingan rakyat.

2. Peneliti menyarankan bagi pelaku usaha pertambangan dan penambang agar bisa mengurus dan melengkapi perizinan serta melakukan kegiatan pengolahan pertambangan dengan mengikuti peraturan-peraturan yang sudah ditentukan agar kedepannya tidak ada pihak yang dirugikan dengan adanya kegiatan pertambangan tersebut sehingga potensi mineral di Kabupaten Ngada dapat diolah dengan baik dan perusahaan yang beroperasi untuk bertanggung jawab atas kerusakan jalan dan kerugian lainnya serta memperhatikan jam kerja operasinya sehingga tidak mengganggu waktu istirahat warga sekitar.

3. Masyarakat sekitar daerah pertambangan harus ikut serta dalam pengawasan kegiatan usaha pertambangan dimana masyarakat sendiri yang mendapatkan efek yang ditimbulkan secara langsung jika ada sesuatu hal yang melanggar yang dilakukan oleh perusahaan pertambangan dan para penambang itu sendiri diharapkan masyarakat harus cepat dan tanggap untuk segera dilaporkan kepada dinas lingkungan hidup ataupun pihak yang berwenang agar proses pengawasan dan penertiban dapat berjalan sesuai dengan apa yang diinginkan.

\section{DAFTAR PUSTAKA}

Efendi. (2014). Kewenangan Pengelolaan Sumber Daya Alam pada Era Otonomi Khusus di Aceh. Yustisia Jurnal Hukum, 3(2), 108-117.

Hadjon, P. M. (1993). Penghantar Hukum Administrasi. University Press. 3

HR, R. (2003). Hukum Administrasi Negara (2nd ed.). UII Press.

Nugroho, K. P. D. S. (2016). Aktualisasi Peran Pemimpin Nasional yang Visioner dapat Mengembangkan Pariwisata Kombes. Kajian Lemhannas RI, 27(September), 25.

Sadjijono. (2008). Memahami Beberapa Bab Pokok Hukum Administrasi NegaraLaks Bang. Pressindo Siagian, S. (1987). Administrasi Pembangunan. PT Gunung Agung.

Soekanto, S. (2013). Penelitian Hukum Normatif. Rajawali Pers.

Suhartono, S. (2013). Desentralisasi Pengelolaan Sumber Daya Alam Untuk Mewujudkan Kesejahteraan Masyarakat. DiH: Jurnal Ilmu Hukum, 9(18), 110-121.

Takalapeta, I. M. ., Pello, J., \& Yohanes, S. (2019). Sinergitas Pengaturan Perizinan Pengelolaan Sumber daya Alam terhadap Konsep Pembangunan Berkelanjutan. Jatiswara, 34(3), 268-282. 